\title{
Trends of the Nanomaterial Market
}

\author{
Prof. Anatoliy Kovalev \\ State University of Management, Moscow, Russia \\ Prof. Sergey Shkarovskiy, State University of Management, \\ High School of Economics, Moscow, Russia
}

\section{Doi:10.5901/mjss.2013.v4n9p655}

\begin{abstract}
The authors analyze theoretical, scientific and economical prerequisites for the world nanotechnological market development. The topicality of this problem is determined by the strategic priority of nanotechnologies in all branches of the world economy to pass to a new type of economy based on knowledge of innovative technologies. A term of «nanotechnological paradigm» is introduced which is a potential for the reconstruction and improvement of production in many branches of modern economy. It is proved by the analysis of development trends of this paradigm in the world economy. Nanotechnologies give a fundamental base for manufacture of new materials and products on molecular level which should be used in the different kinds of human activities. In its turn, this opens new possibilities to evolve all high-tech industries in developed countries. In this article the authors equate market of nanotechnologies and nanoproducts to the market of other products. The structure of this market is determined. According to the forecasts the most developed countries separate nanotechnology market from nanoproduct one.
\end{abstract}

Keywords: nanotechnologies, nanoproducts, nanotechnological paradigm, nanoindustry, innovative products commercialization, marketing, marketing researches.

World economic cycles of economic development have been identified by Kondratiev (so-called «Kondratiev's long waves»). They were appeared during the first Industrial Revolution in England in the end of the XVIII century, its cycle lasts 50 - 55 years. The Austrian scientist Y.Shumpeter put forward the idea of «creative destruction» at the end of each cycle. Friman put forward the concept of «technological paradigm» based on theory about «long waves» of Kondratiev Schumpeter. According to the Friman's concept in each cycle of the world economy development, there is the only «technological paradigm» which defines the priority position of one of the industries in the global economy. ${ }^{1}$

During the period of changes of «technological paradigm» in the global economy, some emerging countries get a window of opportunity to catch up with more developed countries and to reach a higher level of development immediately.2

For Russia this window of opportunity means a full use of nano-technology. Nano-technology is a set of methods and techniques of substance manipulating at the atomic and molecular levels in order to produce final products with the pre-atomic structure. Nano-technologies give an opportunity to create and modify objects which size differ from one molecule to one hundred nanometers. The most important thing is that these objects get a new characteristic, in other words, this is manipulation of substance at those level where its features are defined.

In the foreseeable future, nano-technology can lead to a revolution, exceeding in scale consequences of the widespread computer technology. The «nano-technoeconomic paradigm» can encourage the rapid growth of new industries and services that use nano-technologies. They are potential for reorganization and improvement of production processes in many branches of economy. ${ }^{3}$

Nano-technology has brought about the emergence of a whole series of concepts: nano-materials, nano-systems technology, nano-devices and nano-industry. Nano-industry is a type of activity which creates products based on nanotechnology and nano-materials. In the nano-technology industry markets of various types are formed and developed as nano-complexes: nano-science (sale of licenses, certificates, industrial designs); nano-technologies; nano-products and nano-services; nano-devices and nano-instruments to control nano-technology processes. Any of these markets is a «nano-technoeconomic paradigm» that represents a set of government offices (which support the development of nanoscience and nano-technologies at the macro level), inter-regional scientific and production centers (which at meso-level

1 Шумпетер Й.А. Капитализм, социализм и демократия. М.: Экономика, 1995 г.

2 Кондратьев Н.Д. Большие циклы конъюнктуры и теория предвидения: Избр. тр./Сост.Ю.В.Яковец.-М.: Экономика, 2002-767с.

${ }_{3}^{3}$ Ковалёв А.И. Концептуальные модели прогноза глобального нанорынка и его структура. Журнал «Маркетинг» №3 и №4, 2010г. 
conduct scientific and technological research of nano-products), organizations and individuals (which interact with each other in order to carry out nano-projects and plans). At the micro level market of nano-products is presented by their producers (sellers) and buyers (entities - organizations and individuals), each of which is seeking a commercial benefit from the purchase/sale. «Nano-market» is a market of nano-products, which can be regarded as cooperation between federal agencies, organizations, corporations, associations, research foundations, businesses and individuals in order to get commercial and social benefit for the research and production of nano-materials and nano-products. ${ }^{4}$

Most of the nano-technology market forecasts were made at the beginning of the 2000s with a time horizon till 2015. The real forecast was made by the National Science Foundation (NSF) of the USA. In 2001 this organization wrote a document entitled «International Strategy for Research and Development in the field of nano-technology». ${ }^{5}$ The fundamental principles of the concept are the following:

1. the first market of nano-technology and nano-products was equated to markets of other products manufactured in various industries. The volume of this market was determined (see Table 1);

2. the structure of nano-technology and nano-products market was defined (see Table 2);

3. the estimation of the market was given for the predictable period till 2015 (see Table 3);

4. division of the nano-technology and nano-product market was forecasted by leading countries (see Table 4).

According to this forecast, the volume of the nano-technology and nano-product market in 2015 will make up 1 billion $\$$. In 2005 this forecast was revised by the NSF, the total volume of the market will achieve 2,6 billion $\$$ by 2015 , which will be equal to the $15 \%$ of the total industrial production in the world (see Table 1$){ }^{6}$

Table 1. The estimation of nano-technology and nano-product market for the 2010-2015

\begin{tabular}{|c|c|c|c|c|}
\hline Index & $\begin{array}{l}\text { NSF estimation } \\
\text { of } 2001 \\
\text { for } 2015\end{array}$ & $\begin{array}{r}\text { NSF } \\
0 \\
\text { for } 2010\end{array}$ & $\begin{array}{l}\text { lation } \\
5 \\
\text { for } 2015\end{array}$ & $\begin{array}{c}\text { Share of all } \\
\text { industrial } \\
\text { products }\end{array}$ \\
\hline $\begin{array}{l}\text { Total volume of the world nano- } \\
\text { technology and nano-product market }\end{array}$ & 1bln \$ & 1bln \$ & 2,6 bln $\$$ & $15 \%$ \\
\hline
\end{tabular}

The main poits of the NSF's forecast are given in the tables $2-4 .{ }^{7}$

Table 2. The structure of nano-tecnology market for 2010-2015

\begin{tabular}{|l|c|}
\hline Position & Market share, $\%$ \\
\hline Nano-materials & $30-35$ \\
\hline Semi-conductors & $18-25$ \\
\hline Data storage devices & $15-20$ \\
\hline Bio-technologies & $9-14$ \\
\hline Polymers & $8-12$ \\
\hline Electro-chemistry & $3-5$ \\
\hline Optics & $2-4$ \\
\hline
\end{tabular}

Table 3. Estimation of different branches of nano-technology market for 2015

\begin{tabular}{|l|c|}
\hline Market branches & Value, mIrd \$ per year \\
\hline Nano-materials & 340 \\
\hline Electronics & $>300$ \\
\hline Medicines & 180 \\
\hline Catalysts & 100 \\
\hline Aero-space materials & $\sim 70$ \\
\hline Public health & 20 \\
\hline $\begin{array}{l}\text { Nature protecting } \\
\text { technologies }\end{array}$ & 45 \\
\hline Nano-tools & $\sim 27$ \\
\hline
\end{tabular}

\footnotetext{
${ }_{4}^{4}$ Рынок нано: от нанотехнологий - к нанопродуктам// Под ред. профр. Г.Л. Азоева, М.: БИНОМ. Лаборатория знаний. 2011 г.

${ }^{5}$ www.nsf.gov

${ }^{6}$ www.nsf.gov

7 www.nsf.gov
} 
Table 4. Division of nano-technology market per countries for 2010-2015

\begin{tabular}{|l|c|}
\hline Country & Market share, $\%$ \\
\hline USA & $40-45$ \\
\hline Japan & $25-30$ \\
\hline Europe & $15-20$ \\
\hline Asia & $5-10$ \\
\hline
\end{tabular}

Company «Lux Research»(USA) has elaborated a conceptual model of the global nano-technology market development. According to the model, in 2015 this market will take the following steps:

- the first stage till 2004 - the gradual introduction of experimental nano-materials into different branches of industry;

- the second phase till 2009 - the activisation of nano-research and its following commercialization with domination if nano-electronic products;

- the third phase includes the wide use of nano-products in many industry branches, the share of nanotechnology will reach $15 \%$ of the world production. According to another estimation of the same company, in 2014 the share of nano-technology will rich 14\% of total production that corresponds to the forecast of the NSF. 8

The prospects of nano-technology market seem to be very optimistic. The experts have different opinions concerning the capacity and growth dynamics (see Table 5). ${ }^{9}$

Table 5. Forecasted volume of nano-technology market, trillion \$

\begin{tabular}{|l|c|}
\hline Expert organizations & Volume of market \\
\hline Lux Research, forecast for 2014 & 2,6 \\
\hline US NanoBusiness Alliance, forecast for 2015 & 1,0 \\
\hline Euro Commission, forecast for 2015 & 1,0 \\
\hline Plunkett Research, forecast for 2012-2015 & 1,0 \\
\hline Russian government, forecast for 2017 & 0,3 \\
\hline
\end{tabular}

As it can be seen from the table 5, the nano-product market value differs from $300 \mathrm{bln} \$$ to 2.6 trln $\$$ in 2014 . The calculations of these indicators are made using methods of nano-technology characterization and estimation of the nanotechnology contribution to the value added of final products. According to the most optimistic scenario of nano-product market, the market volume of the products manufactured using nano-technology will be significantly bigger than that of the information and communication technology markets. The volume ofnano-product market will be ten times greater than the volume of the biotechnology market. ${ }^{10}$

According to the company «Lux Research», at the moment the biggest part of nano-technology product market belongs to nano-devices and nano-biotechnology - 420 bln $\$$ and 415 bln \$ respectively, while nano-materials and nanotools have the minor share of market -145 bln $\$$ and 50 bln \$ respectively. The NSF forecast for 2015 indicates that all these branches will expect a significant increase (see Table 3). For example, the volume of nano-materials market will increase from $145 \mathrm{bln} \$$ to $340 \mathrm{bln} \$$, and the share of nano-electronics will reach $300 \mathrm{bln}$ \$. Pharmaceutical, chemical and aerospace industries go after (see Table 3).

However, any actual or projected figures from different sources, which are using different classification, should be compared with caution. Thus in its forecast the NSF uses different categories of nano-materials and their applications (see Tables 2 and 3). The American company «Lux Research» (USA) introduces a classification that uses 4 categories of nano-products / nano-technology: 1) nano-devices (42,0\% of the global market by 2015); 2) nano-biotechnology $(41,0 \%) ; 3)$ nano-materials $(14,0 \%) ; 4)$ tools for nano-technology (3.0\%). ${ }^{11}$

This structure differs from the structure prediction of the NSF. For the first time in its research this company has determined not only different types of nano-products, but also nano-tools that ensure the development of nano-

\footnotetext{
${ }^{8}$ www.nsf.gov

${ }^{9}$ www.cientifica.eu

${ }^{10}$ www.epo.org

${ }^{11}$ www.luxresearchinc.com
} 
technology and are an essential component of the nano-tecnology infrastructure. Later the experts added nano-devices to this group, they are used for manipulation of nano-scale dimensions of the objects and substances. In our forecast we showed another element of the nano-industry structure, namely nano-devices which interact with the environment at the nano-scale level. Thus final classification of nano-tecnology objects was formed: 1) nano-materials; 2) nano-devices; 3) nano-tools. They were included into the Industrial Classification of Foreign Economic Activity (ICFEA) of the Russian Federation.

Among nano-materials widely represented in the ICFEA, we should specify: 1) solid nano-particles; 2) carbon nano-tubes:;3) nano-scale thin tape; 4) nano-structured monolithic materials; 5) nano-composite materials. This classification of nano-materials was adopted by the Institute of Marketing of the State University of Management (SUM) of the Russian Federation. ${ }^{12}$

According to the study made by the «BCC Research» (Great Britain), for the period from 2010 to 2015 the annual average growth rate of the nano-technology global market will be $16,3 \% .13$

These data include such proven methods of commercial applications of nano-materials as converters of exhaust gases on the basis of nano-tape, and new technologies such as the processing of fabrics with nano-particles, production of additives for rocket fuel, equipment for nano-lithography and nano-memory devices.

Introduced in 2004 the three-stage model is still the deepest and the most detailed forecast of the nano-technology market development. According to this model, in the third phase, beginning from 2010, nano-technology will be widely used in production of medical and biotechnological goods and it will penetrate the markets of pharmaceuticals and medical equipment. Nano-biotechnology will vide a significantly contribute to the development of the pharmaceutical industry. By this time, the role of initial nano-materials will be reduced significantly. In 2014 the estimate of the «Lux Research» of nano-biotechnology share makes up 4\% of the total market of manufacturing industries. $100 \%$ of personal computers assemblage, $85 \%$ of production of home electronic goods, $23 \%$ of pharmaceutical products and $21 \%$ of automotive products will use nano-technology. It will give nano-technology a share of $15 \%$ of the world's manufacturing industries in 2014. ${ }^{14}$

The fastest growing segments of the market will be nano-composite materials and solid nano-particles, whose annual growth rate is $28,8 \%$ and $17,5 \%$ respectively. The growth rate of nano-scale thin tapes will be annually of $7.5 \%$, and nano-structured solid materials - 9.4\%. Market forecast solves a very important problem - the estimation of the prospects for the use of nano-materials in various industries.

The value of scientific knowledge in the field of nano-technologies is determined by the following factors:

- the practical utility for the welfare of all people;

- a significant increase in the intellectual and educational potential of all members of the world community;

- the promotion of scientific, technical, economic and social progress of the global community;

- $\quad$ increase of the adaptive capacity of human individual for interaction with the environment;

- increasing possibilities of human civilization in the protection of life on Earth. ${ }^{15}$

Nano-technologies provide a fundamentally new basis in the form of technologies, atomic molecular construction of new materials and products with predetermined properties required for use in various fields of human activities. This fact opens opportunities for the development of all sectors of new knowledge-based economy. Therefore, knowledge of the nano-world, «nano-science» must be regarded as the most important factor of the new economy. At the same time, nano-science will allow to find and use high technology for greater processing of natural resources available in the country and to learn how to recycle and safely utilize all industrial and domestic waste of human civilization. ${ }^{16}$

The beginning of the XXI century was marked by the development of the most important scientific and creative potentials of researchers, which led to significant scientific discoveries, as well as to the increased attention from the governments of various countries to the problems of the nano-technology development.

Over past 10 years the governments of U.S., Germany, France, Japan and China have significantly developed research in the field of nanotechnology. In these countries programs of nanotechnology development was approved on the level of national priority. According to the consulting company «Lux Research», in 2010 the governments,

\footnotetext{
12 Рынок нано: от нанотехнологий - к нанопродуктам// Под ред. проф. Г.Л. Азоева, М.: БИНОМ. Лаборатория знаний. 2011 г.

${ }^{13}$ www.bccresearch.com

${ }^{14}$ www.luxresearchinc.com

${ }_{15}$ Азоев Г.Л. Маркетинговый анализ рынка нанопродуктов (Результаты аналитического проекта). Журнал «Маркетинг» №5 (108)/2009. М.: Издательство «Центр маркетинговых исследований и менеджмента» - 2009 г

16 Ковалёв А.И. Концептуальные модели прогноза глобального нанорынка и его структура. Журнал «Маркетинг» №3 и №4, 2010

г. 
corporations and private businesses around the world have spent about 9 bln $\$$ on research in the field of nanotechnology, the number of registered patents is more than 90 thousand. The annual government investment into the research makes up $800 \mathrm{mln} €$ in the European Community, about $800 \mathrm{mln} \$-$ in the U.S.A., up to $500 \mathrm{mln} \$-$ in Japan, and finally $100 \mathrm{mln} \$-$ in Cina.

According to the forecast of the NSF, in 2015 the annual turnover of the global nano-technology market will reach 1 trln \$, and 2 million peolpe throughout the world will work in this field. People will be distributed geographically in the follow way: 0,8-0,9 million in the United States, 0,5-0,6 million in Japan, 0,3-0,4 million in Europe, about 0,2 million in Asia-Pacific (excluding Japan), and 0,1 million in other regions. In addition, this would create 5 million extra jobs related to nano-technology. And finally, according to the «Lux Research» by 201410 million work stations will be created, directly related to the production in the field of nano-technology.

\section{References}

www.bccresearch.com

www.cientifica.eu

www.epo.org

www.luxresearchinc.com

www.nsf.gov

Азоев Г.Л. Маркетинговый анализ рынка нанопродуктов (Результаты аналитического проекта). Журнал «Маркетинг» №5 (108)/2009. М.: Издательство «Центр маркетинговых исследований и менеджмента» - 2009 г.

Ковалёв А.И. Концептуальные модели прогноза глобального нанорынка и его структура. Журнал «Маркетинг» №3 и №4, 2010 г. Кондратьев Н.Д. Большие циклы конъюнктуры и теория предвидения: Избр. тр./Сост.Ю.В.Яковец.-М.: Экономика, $2002-767$ с.

Рынок нано: от нанотехнологий - к нанопродуктам// Под ред. проф. Г.Л. Азоева, М.: БИНОМ. Лаборатория знаний. 2011 г. Шумпетер Й.А. Капитализм, социализм и демократия. М.: Экономика, 1995 г. 